\title{
CrimRxiv
}

\section{Grey Area: Regulating Amsterdam's Coffeeshops}

\section{Scott Jacques}

Published on: Mar 04, 2022

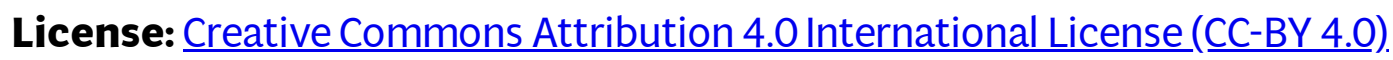


